\title{
ANALISIS PERBANDINGAN INTERNET FINANCIAL REPORTING INDEX BANK UMUM SYARIAH DI INDONESIA, MALAYSIA, IRAN, DAN SUDAN
}

\author{
Putri Septiani Dwi Hayati \\ Prodi Ekonomi Islam, Fakultas Ekonomi dan Bisnis, Universitas Airlangga \\ Email: putriiseptiani@gmail.com
}

Noven Suprayogi

Prodi Ekonomi Islam, Fakultas Ekonomi dan Bisnis, Universitas Airlangga

Emal: noven.suprayogi@feb.unair.ac.id

ARTICLE HISTORY

Received:

130ktober 2018

Accepted:

1 November 2018

Online available:

2 November 2018

Keywords:

Reporting,

Indonesia,

Malaysia, Iran,

Sudan
Internet Financial

\section{ABSTRACT}

The purpose of this study was to determine the differences of Internet Financial Reporting Quality. This study was using quantitative approach with one way anova and kruskal wallis. The population of this study was official website of islamic banks in Indonesia, Malaysia, Iran, Sudan. The data was collected from official website sentral bank in each country and official website of islmaic bank in each country. Data that being used was primary data. The result of this study showes that there was significant differences of Internet Financial Reporting Quality between Indonesia, Malaysia, Iran, Sudan. The difference is caused there are significant differences between the quality of content, timeliness, user support components. Meanwhile, there is no differences between technology components.

\section{ABSTRAK}

Kata Kunci:

Pelaporan

Keuangan Internet, Indonesia, Malaysia, Iran, dan Sudan
Tujuan dari penelitian ini adalah untuk mengetahui perbedaan antara Kualitas Laporan Keuangan Internet. Penelitian ini menggunakan pendekatan kuantitatif dengan anova satu arah dan kruskal wallis. Populasi dari penelitian ini adalah website resmi dari bank syari'ah di Indonesia, Malaysia, Iran, dan Sudan. Data didapatkan melalui website resmi bank sentral setiap negara dan website resmi resmi bank syari'ah di setiap negara. Data yang digunakan dalam penelitian ini adalah data primer. Hasil penelitian ini menunjukkan bahwa ada perbedaan yang signifikan dari kualitas laporan keuangan internet di Indonesia, Malaysia, Iran, dan Sudan. Perbedaan ini disebabkan karena terdapat perbedaan yang mencolok pada kualitas konten, timeline dan komponen bantuan 
user. Meski demikian tidak ditemukan adanya perbedaan di antara komponen teknologi.

\section{PENDAHULUAN}

\section{Latar Belakang}

Perbankan syariah sebagai suatu entitas bisnis yang menjunjung transparansi wajib menyusun dan menyajikan laporan keuangan sebagaimana yang ditetapkan dalam Peraturan Otoritas Jasa Keuangan Nomor 32 Tahun 2016 tentang transparansi dan publikasi laporan keuangan.Perbankan syariah harus melakukan pengungkapan informasi secara transparan, penerapan dalam pelaporan informasi keuangan secara optimal diharapkan dapat memberikan respon posistif kepada pengguna laporan keuangan.

Dalam pengoperasian perbankan syariah terdapat dua sistem yang digunakan di beberapa negara yaitu,dual banking system dan full fledged islamic banking system. Jika dual banking system merupakan sistem yang mengatur dua jenis perbankan untuk beroperasi bersama-sama dalam sistem perbankan nasional, maka full fledged islamic banking merupakan sistem yang mengharuskan perbankan suatu negara beroperasi secara penuh sesuai dengan syariah (GIFR,2016). Indonesia dan Malaysia merupakan negara yang menerapkan dual banking system sementaralran dan Sudan merupakan negara yang menerapkan full fledged islamic banking.

Pengungkapan laporan keuangan melalui internet atau Internet Financial Reporting (IFR) merupakan suatu cara dalam menyebarkan informasikeuangan melalui situs website perusahaan tersebut. Internet Financial Reporting (IFR) masih memiliki hubungan dengan teori sinyal, dimana teori tersebut memanfaatkan informasi laporan keuangan untuk memberi sinyal positif maupun negatif kepada pihak luar guna mengurangi adanya asimetri informasi. Indeks untuk merumuskan kualitas dari pengungkapan informasi keuangan perusahaan melalui internet atau website yang dimiliki perusahaan disebut dengan Internet Financial Reporting Index (IFRI).

Perkembangan internet yang semakin pesat dan mampu menyediakan informasi dari berbagai penjuru dunia, dapat digunakan sebagai pemicu dalam penggunaan IFR perbankan syariah di beberapa negara khususnya negara yang menerapkan dual banking system dengan negara yang menerapkan full fledged Islamic banking.

Berdasarkan latar belakang diatas maka rumusan masalah dalam penelitian ini apakah terdapat perbedaan yang signifikan pada indeks IFR bank umum syariah di negara menerapkan dual banking system(Indonesia, Malayisa)dengan full fledged islamic banking(Iran, Sudan). Tujuan penelitian ini adalah untuk mengetahui apakah terdapat perbedaan yang signifikan pada indeks IFR bank umum syariah di negara menerapkan dual banking system dengan full fledged Islamic banking. 


\section{LANDASAN TEORI}

\section{Teori Keagenan}

Hubungan agen muncul ketika individu atau lebih yang disebut pemilik (principal) mempekerjakan individu lain atau organisasi yang disebut agen untuk melaksanakan pekerjaan yang kemudian mendelegasikan otorisasi pengambilan keputusan kepada agen tersebut. Akibat pendelegasian wewenang oleh pemilik perusahaan untuk pembuatan keputusan, maka memicu timbulnya konflik atas kepentingan yang disebut teori keagenan (Brigham dan Houston,2001:22). Adanya hubungan antara principal dengan agen ini dapat menyebabkan asimetri informasi, karena agen berada di posisi yang memiliki informasi yang lebih banyak tentang perusahaan dibandingkan dengan principal.

Masalah teori keagenan sebenarnya dapat dikurangi dengan meningkatkan pengungkapan. Peningkatan transparansi dan pengungkapan secara tepat waktu dalam laporan keuangan menyebabkan manajer secara lebih insentif bertindak untuk kepentingan pemegang saham, sehingga peningkatan transparansi dan pengungkapan akan memberikan kontribusi dalam menyelaraskan kepentingan manajer dan pemegang saham (Ball, 2006:11).

\section{Teori Sinyal}

Teori sinyal menjelaskan tentang bagaimana suatu perusahaan memberikan petunjuk kepada investor tentang informasi keuangan dan prospek perusahaan (Brigham dan Houston,2011:214). Sebuah perusahaan seharusnya memberikan sinyal kepada pengguna laporan keuangan, sinyal tersebut dapat berupa informasi mengenai apa yang sudah dilakukan manajemen untuk merealisasikan keinginan pemilik, ataupun informasi lain yang menyatakan bahwa perusahaan tersebut lebih baik dari perusahaan lain (Handayani dan Almilia, 2013:102).Pelaporan keuangan dapat digunakan perusahaan untuk memberikan sinyal kepada pemangku kepentingan. Sinyal tersebut dapat berupa informasi yang bersifat keuangan dan non keuangan yang keduanya dibutuhkan investor untuk mengambil keputusan.

Teori sinyal sendiri dapat digunakan untuk memprediksi kualitas pengungkapan informasi perusahaaan yang menggunakan internet sebagai medianya.Dengan pelaksanaan IFR secara baik dan maksimal dapat memberi sinyal kepada para pemangku kepentingan bahwa bank syariah telah melakukan pelaporan keuangan dengan baik. Hal ini tentunya menjadi sinyal positif dan akan memberikan keuntungan bagi bank syariah tersebut.

\section{Laporan Keuangan Bank Umum Syariah}

Laporan keuangan syariah dijelaskan dalam PSAK nomor 101, laporan keuangan syariah merupakan penyajian terstruktur dari posisi keuangan dan kinerja suatu entitas syariah sebagai bentuk pertanggungjawaban manajemen yang bertujuan memberikan informasi mengenai posisi keuangan.Laporan keuangan menyediakan informasi 
menyangkut posisi keuangan, perubahan posisi keuangan serta kinerja perusahaan tersebut. Sehingga laporan keuangan dapat digunakan sebagai pengambilan suatu keputusan bagi pihak yang berkepentingan. Informasi dalam laporan keuangan harus dapat dipahami, relevan, serta dapat diperbandingkan sehingga perusahaan akan mendapatkan kepercayaan dari para investor.

\section{Internet Financial Reporting (IFR)}

Internet Financial Reporting (IFR) merupakan suatu cara dalam menyampaikan informasi keuangan melalui website perusahaan tersebut. Penggunaan IFR pada perusahaan memberikan manfaat bagi penggunanya, manfaat yang diperoleh yaitu meningkatkan ketepatan waktu dan efisiensi dalam memperoleh informasi keuangan, membuat proses keputusan investasi lebih mudah dan lebih cepat, dan memberikan informasi dengan biaya yang murah (Khan dan Ismail, 2013) dalam (Khan, 2015:780).Penggunaan website dalam penyampaian laporan keuangan mulai diatur dalam peraturan OJK yaitu melalui Peraturan OJK Nomor X.K.6 tahun 2012 dengan lampiran Keputusan Ketua OJK Nomor KEP-431/BL/2012 tentang Penyampaian Laporan Tahunan Emiten atau Perusahaan Publik. Peraturan tersebut menjelaskan bahwa emiten atau perusahaan publik diwajibkan untuk memuat laporan tahunan tersebut pada laman atau website perusahaan selain penyampaian dalam bentuk fisik atau hardcopy kepada OJK.

\section{Internet Financial Reporting Index (IFRI)}

Internet Financial Reporting Index (IFRI) merupakan suatu alat ukur yang digunakan untuk mengukur kualitas internet financial reporting dalam website perusahaan.Internet Financial Reporting Index (IFRI) dikembangkan oleh (Cheng et.al 2002) dalam (Handayani dan Almilia 2013) yang memiliki empat komponen.Keempat komponen indeks tersebut meliputi isi/content, ketepatwaktuan/timeline, pemanfaatan teknologi/technology dan dukungan pengguna/user support.Website perusahaan yang memiliki kualitas Internet Financial Reporting yang bagus akan memberkan informasi yang lengkap serta mempermudah investor untuk mendapatkan informasi yang dibutuhkan.

Insani (2016) dalam penelitiannyatentangAnalisis Perbandingan Kualitas Internet Financial Reporting Bank Umum Syariah Di Indonesia Dan Malaysia. Penelitian ini menunjukkan bahwa terdapat perbedaan yang signifikan antara kualitas Internet Financial Reporting, komponen content IFR Bank Umum Syariah di Indonesia dan Malaysia.

\section{Content}

Content/isi merupakan isi dari website perbankan syariah mengenai kelengkapan informasi keuangan yang disajikan. Informasi keuangan yang diungkapkan dalam bentuk html lebih memudahkan pengguna untuk mengakses informasi keuangan secara efektif 
dan cepat. Sehingga, informasi keuangan dalam bentuk html memiliki skor yang lebih tinggi daripada dengan format pdf.

Widari, dkk (2018) dalam penelitiannya tentang Analisis Internet Financial Reporting (Studi Perusahaan Manufaktur yang Go Public di Indonesia, Singapura, dan Malaysia). Penelitian ini menunjukkan bahwa terdapar perbedaan dari sisi content IFR.

\section{Timeliness}

Timeliness/ketepatwaktuan berkaitan dengan penyajian informasi keuangan perusahaan secara tepat waktu. Pelaporan informasi baik keuangan maupun data perusahaan secara tepat waktu dan up to date akan memudahkan investor dalam pengambilan keputusan. Komponen penilaian ketepatwaktuan terdiri dari press release, unaudited last quarterly result, stock quote, visions statement. Penilaian komponen timeliness dikatakan tepat waktu apabila update berita atau informasi adalah untuk minggu ini. Jika update berita atau informasi lebih dari satu minggu maka nilainya akan lebih rendah.

Insani (2016) juga dalam penelitiannya tentang Analisis Perbandingan Kualitas Internet Financial Reporting Bank Umum Syariah Di Indonesia Dan Malaysia. Penelitian ini menunjukkan bahwa terdapat perbedaan yang signifikan antara kualitas komponen timeliness IFR Bank Umum Syariah di Indonesia dan Malaysia.

\section{Technology}

Technology berkaitan dengan pemanfaatan teknologi yang digunakan oleh perusahaan dalam pelaporan informasi keuangan melalui internet, yang tidak dapat disediakan oleh media cetak (Handayani dan Almilia, 2013: 104). Komponen tersebut antara lain penggunaan teknologi multimedia, analysis tools, download plug-in on spot, online feedback and support, presentation slide dan fitur - fitur lanjutan (seperti implementasi intelligent agent atau XBRL). Pemanfaatan teknologi pada website perusahaan dapat mempermudah pengguna dalam mengakses informasi. Semakin berkualitas komponen teknologi yang digunakan dalam website perusahaan maka indeksnya akan semakin tinggi.

Rahmawati(2016) dalam penelitiannya tentang Analisis Perbandingan Internet Financial Reporting (IFR) Pada Sektor Perbankan Yang Go Public Di Indonesia, Malaysia, Dan Singapura.Penelitian menunjukkan bahwaterdapat perbedaan indeks komponen technology antara sektor perbankan yang go public di negara Indonesia, Malaysia, dan Singapura.

\section{User Support}

Dukungan pengguna/user support yang dimaksudkan dalam penelitian ini adalah keberagaman fasilitas dan layanan yang disediakan perusahaan dalam website nya untuk memudahkan penggunanya. Fasilitas tersebut antara lain helpand frequently asked question (FAQ), link to homepage, link to top, site map, site search, consistency of web 
page design, number of click to get financial information. Indeks perusahaan akan semakin tinggi apabila perusahaan mampu mengimplementasikan secara optimal semua sarana dalam website perusahaan.

Handayani dan Almilia(2013) dalam penelitiannya tentang Internet Financial Reporting: Studi Komparasi Manufaktur yang terdaftar di Bursa Efek Indonesia dan Bursa Efek Malaysia. Penelitian ini menunjukkan terdapat perbedaan yang signifikan pada komponen user support IFR.

Berdasarkan landasan teori yang telah dijelaskan sebelumnya, maka dapat dibuat model analsis Sebagai berikut:

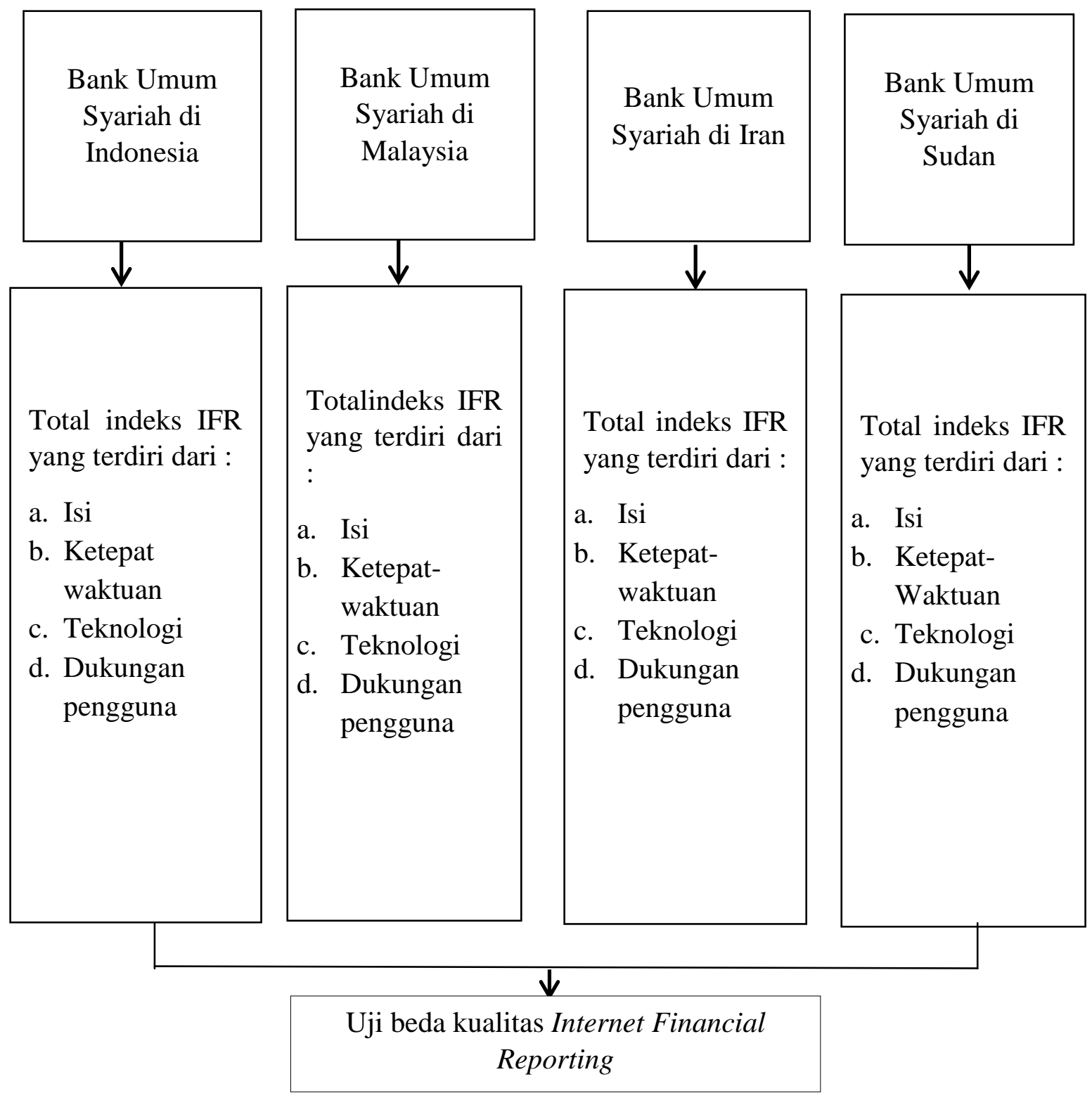

Sumber: Penulis

Gambar 1.1 Model Analisis

Sehingga penelitian ini dapat mengajukan hipotesis sebagai berikut: 
H1 : Terdapat perbedaan yang signifikan pada rata-rata kualitas Internet Financial Reporting Bank Umum Syariah di Indonesia, Malaysia, Iran , dan Sudan

$\mathrm{H} 2$ : Terdapat perbedaan yang signifikan pada rata-rata kualitas komponen content IFR Bank Umum Syariah di Indonesia, Malaysia, Iran, dan Sudan.

H3 : Terdapat perbedaan yang signifikan pada rata-rata kualitas komponen timelines IFR Bank Umum Syariah di Indonesia, Iran, dan Sudan.

H4 : Terdapat perbedaan yang signifikan pada rata-rata kualitas komponen technology IFRBank Umum Syariah di Indonesia, Malaysia, Iran dan Sudan.

H5 : Terdapat perbedaan yang signifikan padarata-rata kualitas komponen user support IFR Bank Umum Syariah di Indonesia, Malaysia, Iran dan Sudan.

\section{METODE PENELITIAN}

\section{Klasifikasi Sampel}

Populasi yang digunakan dalam penelitian adalah website Bank Umum Syariah masing - masing negara (Indonesia, Malaysia, Iran, Sudan). Sampel yang digunakan adalah semua website resmi bank umum syariah di Indonesia, Malaysia, Iran, Sudan. Data yang dianalisis sebanyak 13 Bank Syariah di Indonesia, 17 Bank Syariah di Malaysia, 26 Bank Syariah di Iran, 24 Bank Syariah di Sudan.Dengan demikian terdapat 80 observasi.

\section{Data Penelitian}

Penelitian dengan menggunakan pendekatan kuantitatif. Jenis data yang digunakan dalam penelitian ini adalah data sekunder yang diperoleh dengan melakukan observasi secara langsung melalui website resmi Bank Umum Syariah di Indonesia, Malaysia, Iran, dan Sudan. Teknik pengumpulan data dilakukan dengan mengumpulkan data yang bersumber dari website bank umum syariah masing-masing Negara.

Alat yang digunakan dalam pengumpulan data yaitu dengan menggunakan form checklist indeks IFR untuk menilai kualitas IFR masing-masing Bank Umum Syariah di Indonesia, Malaysia, Iran, dan Sudan. Penelitian ini menggunakan uji beda one way anova dengan data yang terdistibusi normal, dan kruskal wallis dengan data yang tidak terdistribusi normal.

\section{Definisi Operasional Variabel}

\section{Isi/Content}

Isi/Content ini meliputi informasi keuangan seperti laporan tahunan atau laporan triwulan yang ditampilkan di website Bank Umum Syariah. Semakin banyak laporan terbaru maka akan semakin tinggi pula nilai yang diperoleh. Penilaian selanjutnya mengenai pengggunaan bahasa pada website Bank Umum Syariah. Bank Umum Syariah yang menyediakan pilihan bahasa inggris dan bahasa lain memiliki nilai yang lebih tinggi. 
Informasi ketersediaan saham pada website Bank Umum Syariah menjadi penilaian selanjutnya. Bank Umum Syariah yang menyediakan informasi saham pada website nya memiliki nilai yang lebih tingga daripada Bank Umum Syariah yang tidak menyediakan informasi saham. Penilaian yang terakhir mengenai format informasi keuangan yang bersangkutan. Apabila informasi keuangan tersebut tersedia dalam format HTML maka nilainya lebih besar daripada yang menggunakan format PDF.

\section{Ketepatwaktuan/timeliness}

Bank Umum Syariah yang menyajikan informasi keuangan pada website dengan tepat waktu, akan semakin tinggi indeksnya. Pemanfaatan informasi secara tepat waktu oleh stakeholder dalam pengambilan keputusan merupakan tujuan utama penerapan IFR pada Bank Umum Syariah. Terdapat empat komponen dalam ketepawaktuan/timeliness pada indeks IFR yang perlu diperhatikan. Pertama, tersedianya press release. Press release merupakan informasi yang berbentuk berita untuk menumbuhkan citra positif sebagai salah satu bentuk komunikasi perusahaan dengan stakeholdernya. Kedua, tersedianya Unaudited Last Quarterly Result atau biasa disebut dengan laporan triwulanan yang belum diaudit. Ketiga, tersedianya Stock Quote, yang dimaksudkan disini yakni konsistensi dalam memberikan kutipan saham. Keempat, Vision Statement, yang dimaksudkan disini tersedianya pernyataan perkiraan masa depan perusahaan tersebut.

\section{Dukungan pengguna/user support}

Dukungan pengguna/user support merupakan komponen indeks IFR yang menilai keberagaman failitas yang disediakan Bank Umum Syariah dalam website untuk mendukung keberagaman penggunanya. Bank Umum Syariah yang mengimplementasikan secara optimal sarana dalam website perusahaan maka akan semakin tinggi nilainya. Dalam dukungan pengguna/user support terdapat tujuh komponen yang dinilai. Pertama, help and frequently asked question, merupakan format daftar informasi online berupa pertanyaan yang sering diajukan orang dan jawabannya sudah tersedia dalam website tersebut. Kedua, link to homepage, pengaksesan halaman web dapat berpindah dengan cepat ke halaman utama atau homepage website Bank Umum Syariah. Ketiga, link to top, memungkinkan pengaksesan halaman web berpindah dengan cepat ke bagian paling atas halaman yang sama dengan yang diakses pada website Bank Umum Syariah (EMS, 2015:131 dalam Insani, 2016:34). Keempat, site map, berupa file yang berisi link ke konten - konten yang ada di dalam website.Kelima, site search, yakin memudahkan pengguna untuk menemukan konten yang dicari dengan cepat.Keenam, consistency of web page design, berkaitan dengan konsistensi desain website seperti tata letak menu bar atau icon-icon tertentu.Ketujuh, number of click to get financial information, berkaitan dengan kemudahan dan kecepatan dalam mengakses website Bank Umum Syariah.Semakin sedikit (dalam melalukan klik), maka semakin mudah dan cepat pengguna dalam mendapatkan laporan keuangan. 


\section{Pemanfaatan teknologi/technology}

Komponen ini berhubungan dengan pemanfaatan teknologi yang mempermudah pengguna untuk mengakses informasi yang ada dalam website perusahaan. Terdapat enam komponen dalam penilaian pemanfaatan teknologi/technology. Pertama, download plug-in on spot, yakni ketersediaan link untuk mengunduh aplikasi yang dibutuhkan untuk membuka informasi yang diunduh dari website Bank Umum Syariah. Kedua, online feedback and support, merupakan umpan balik ataupun tanggapan dari pengguna yang bisa langsung disampaikan via online. Ketiga, presentation slide, yakni penggunaan slide presentasi yang diunggah di website Bank Umum Syariah sehingga dapat digunakan sebagai strategi e-bisnis (Winarno, 2015a:100 dalam Insani, 2016:34). Keempat, multimedia technology, merupakan penggunaan berbagai macam media yang digunakan untuk menggabungkan dan menyampaikan informasi dalam bentuk teks, audio, grafik, animasi dan video (Munir,2012:162). Kelima, analysis tool, merupakan alat analisis yang disediakan oleh website Bank Umum Syariah untuk mendukung kebutuhan pengguna. Keenam, advance features, merupakan suatu fitur lanjutan yang dapat digunakan pengguna untuk mengakses informasi melalui website perusahaan, seperti intelligent agent atau XBRL (Handayani \& Almilia,2013:104).

\section{HASIL PENELITIAN DAN PEMBAHASAN}

Untuk mengetahui gambaran mengenai karakteristik sampel yang digunakan dapat dilihat dari nilai rata-rata, standar deviasi, maksimum, minimum.

Tabel 1

Data Deskriptif

\begin{tabular}{llllll}
\hline $\begin{array}{l}\text { NAMA } \\
\text { NEGARA }\end{array}$ & CONTENT & TIMELINESS & $\begin{array}{l}\text { TECHNO } \\
\text { LOGY }\end{array}$ & $\begin{array}{l}\text { USER } \\
\text { SUPPORT }\end{array}$ & IFR \\
\hline INDONESIA & 29.6154 & 4.615 & 4.7692 & 9.9231 & 49.230 \\
\hline MALAYSIA & 23.6176 & 4.206 & 5.4118 & 9.4706 & 42.500 \\
\hline IRAN & 19.3269 & 2.615 & 3.9231 & 8.9231 & 35.173 \\
\hline SUDAN & 16.8125 & 1.729 & 4.4167 & 7.0417 & 29.917 \\
\hline
\end{tabular}

Sumber: EMS, 2015:131 dalam Insani, 2016:34

Berdasarkan tabel diatas menunjukkan bahwa nilai rata-rata untuk total indeks Internet Financial Reporting pada website Bank Umum Syariah di Indonesia yaitu sebesar 49.2308. Nilai rata-rata untuk komponen content IFR pada website Bank Umum Syariah di Indonesia sebesar 29.6154. Nilai rata-rata untuk komponen timeliness IFR sebesar 4.6154. Dan nilai rata-rata untuk komponen technology IFR sebesar 4.7692. 
Berdasarkan tabel tersebut menunjukkan bahwa nilai rata-rata untuk total indeks Internet Financial Reporting pada website Bank Umum Syariah di Malaysia yaitu sebesar 42.5000. Nilai rata-rata untuk komponen content IFR website Bank Umum Syariah di Malaysia sebesar 23.6176.Nilai rata-rata komponen timeliness IFR sebesar 4.2059. Nilai rata-rata untuk komponen technologyIFR sebesar 5.4118. Dan nilai rata-rata untuk komponen user support IFR pada website Bank Umum Syariah di Malaysia sebesar 9.4706 .

Berdasarkan tabel tersebut menunjukkan bahwa nilai rata-rata untuk total indeks Internet Financial Reporting pada website Bank Umum Syariah di Iran yaitu sebesar 35.1731. Nilai rata-rata untuk komponen content IFR pada website Bank Umum Syariah di Iran y sebesar 19.3269. Nilai rata-rata untuk komponen timeliness IFR sebesar 2.6154.Nilai rata-rata untuk komponen technology IFR sebesar 3.9231. Dan nilai rata-rata untuk komponen user support IFR pada website Bank Umum Syariah di Iran yaitu sebesar 8.9231.

Berdasarkan tabel tersebut menunjukkan bahwa nilai rata-rata untuk total indeks Internet Financial Reporting pada website Bank Umum Syariah di Sudan yaitu sebesar 29.9167. Nilai rata-rata untuk komponen content IFR pada website Bank Umum Syariah di Sudan sebesar 16.8125.Nilai rata-rata untuk komponen timeliness IFR sebesar 1.7292. Nilai rata-rata untuk komponen technology IFR sebesar 4.4167.Dan nilai rata-rata untuk komponen user support IFR pada website Bank Umum Syariah di Sudan yaitu sebesar 7.0417.

\section{Kualitas Internet Financial Reporting}

Berdasarkan uji one way anova, total rata-rata internet financial reporting antara Bank Umum Syariah di Indonesia, Malaysia, Iran, Sudan terdapat perbedaan yang signifikan, dengan nilai signifikansinya $0.00<0.05$. Pada analisis deskriptif, rata-rata total indeks Internet Financial Reporting Bank Umum Syariah lebih besar daripada total Internet Financial Reporting Bank Umum Syariah di Malaysia, Iran, Sudan. Hal tersebut menunjukkan bahwa kualitas Internet Financial Reporting Bank Umum Syariah di Indonesia lebih baik dibandingkan bank umum syariah di ketiga negara tersebut.

Penyebab terjadinya perbedaan Internet Financial Reporting, adanya perbedaan yang signifikan dari sisi content IFR, timeliness IFR, serta user support IFR. Kurang lengkapnya informasi keuangan yang disediakan website bank syariah di Iran dan Sudan menjadi salah satu penyebab terjadinya perbedaan. Perbankan syariah di Iran sangat sedikit yang menampilan quarterly result/laporan triwulan di website mereka. Sedangkan dari segi bahasa yang digunakan, terdapat beberapa bank yang tidak menggunakan bahasa inggris di website mereka baik di Indonesia, Malaysia, Iran, dan Sudan. Hal tersebut tentu akan menyulitkan bagi pengguna laporan keuangan dari negara lain untuk melihat kondisi dari perbankan syariah tersebut. Selain dari sisi laporan keuangan dan bahasa, laporan CSR (Coorporate Social Responsibility) merupakan salah satu penyebab adanya perbandingan 
yang signifikan. Perbankan syariah di Iran dan Sudan sangat sedikit yang menampilkan laporan CSR baik dengan format PDF atupun HTML.

Press release juga merupakan salah satu penyebab terjadinya perbedaan yang signifikan pada kualitas IFR di keempat negara tersebut. Update berita di bank umum syariah Indonesia, Malaysia, Iran, Sudan memiliki konsistensi yang berbeda-beda. Untuk bank syariah di Iran dan Sudan memiliki nilai yang rendah dalam update berita, karena kebanyakan dari bank syariah di Iran dan Sudan hari terakhir update beritanya lebih dari satu bulan. Selain press release, unaudited last quarterly result merupakan penyebab adanya perbedaan yang signifikan. Untuk Bank Umum Syariah di Indonesia dan Malaysia hampir semuanya memberikan hasil laporan triwulan yang belum diaudit. Sementara untuk Bank Umum Syariah di Iran dan Sudan tidak menampilan laporan triwulan di website, yang tentunya juga tidak memberikan hasil laporan triwulan yang belum diaudit.

Help and Frequently Asked Question (FAQ) merupakan daftar informasi online berupa pertanyaan yang sering diajukan dan jawabannya sudah tersedia dalam websitetersebut. Help and FAQ ini menjadi penyebab juga adanya perbandingan yang signifikan. Bank Umum Syariah di Sudan sama sekali tidak menggunakan help and FAQ pada websitenya.Selain dari sisi content, timeliness, dan user support penyebab lain kualitas IFR Indonesia menunjukkan nilai yang tinggi adalah adanya regulasi dan sanksi tegas terkait pelaporan informasi keuangan. Dalam peraturan tersebut dijelaskan bahwa bank umum syariah diwajibkan untuk menyampaikan laporan keuangan. Apabila bank syariah tidak mematuhi peraturan tersebut maka akan mendapatkan sanksi administrasi sesuai dengan Peraturan Otoritas Jasa Keuangan Nomor 32 Tahun 2016 tentang transparansi dan publikasi laporan keuangan.

Internet Financial Reporting merupakan salah satu cara bank umum syariah untuk menjaga kepercayaan stakeholdernya yang didalamnya termasuk investor dan kreditor. Investor dan kreditor merupakan orang yang telah meletakkan kepercayaannya pada bank umum syariah, sehingga sudah sepatutnya Bank Umum Syariah di Indonesia memaksimalkan pelaporan keungan melalui website guna mencegah adanya asimetri informasi yang dapat merugikan pihak perbankan sendiri.

\section{Kualitas Content}

Berdasarkan uji one way anova,komponen content IFRantara Bank Umum Syariah di Indonesia, Malaysia, Iran, Sudan terdapat perbedaan yang signifikan, dengan nilai signifikansinya $0.00<0.05$. Pada analisis deskriptif, komponen content Bank Umum Syariah Indonesia lebih besar daripada komponen content Bank Umum Syariah di Malaysia, Iran, Sudan. Hal tersebut menunjukkan bahwa kualitas dari sisi content IFR Bank Umum Syariah di Indonesia lebih baik dibandingkan bank umum syariah di ketiga negara tersebut.

Komponen content IFR yang menilai tentang kelengkapan isi informasi yang disajikan, Bank Umum Syariah Indonesia mengungkapan informasi yang lebih baik, 
lengkap, dan memadai bagi stakeholdernya dibandingkan Bank Umum Syariah di Malaysia, Iran, dan Sudan. Indonesia dalam pengungkapan informasi keuangan cukup lengkap dibandingkan negara lain, baik berupa laporan tahunan dan laporan triwulan dari beberapa periode. Selain itu, informasi tentang bank umum syariah juga lengkap dengan menampilkan visi misi perusahaan, kontak investor, susunan pengurus, dan tanggung jawab sosial perusahaan.Itulah yang menyebabkan Indonesia memiliki nilai rata-rata yang lebih tinggi.Sementara, untuk Bank Umum Syariah di Malaysia beberapa bank tidak menampilkan laporan dengan lengkap seperti tidak adanya laporan tahunan/laporan triwulan dalam webiste mereka.Bahkan untuk Bank Umum Syariah Sudan tidak ada satupun bank yang menampilkan laporan triwulan pada website mereka, sehingga hal ini yang menyebabkan nilai dari sisi contentnya berada dibawah Indonesia.Padahal pengungkapan informasi keuangan yang lengkap dan bagus dapat dianggap sebagai sinyal positif yang berdampak pada respon positif oleh stakeholder sehingga menguntungkan bagi bank syariah itu sendiri.

\section{Kualitas Timeliness}

Berdasarkan hasil uji kruskal wallis, komponen timeliness IFRantara Bank Umum Syariah di Indonesia, Malaysia, Iran, Sudan terdapat perbedaan yang signifikan, dengan nilai signifikansinya $0.00<0.05$. Dalam komponen timeliness dilakukan uji kruskal wallis karena data tidak terdistribusi normal dengan nilai signifikani $<0.05$. Pada analisis deskriptif, komponen timeliness IFRBank Umum Syariah Indonesia lebih besar daripada komponen timeliness IFRBank Umum Syariah di Malaysia, Iran, Sudan. Hal tersebut menunjukkan bahwa kualitas dari sisi timeliness IFR Bank Umum Syariah di Indonesia lebih baik dibandingkan bank umum syariah di ketiga negara tersebut. Dari sisi timeliness IFR, yang menilai tentang kebaruan informasi yang disajikan, Bank Umum Syariah Indonesia juga memiliki kualitas lebih baik dibandingkan Bank Umum Syariah di Malaysia, Iran, dan Sudan. Ini menunjukkan bahwa Bank Umum Syariah Indonesia lebih konsisten dalam melalukan update informasi keuangan. Pelaporan informasi baik keuangan maupun data perusahaan secara tepat waktu dan up to dateakan memudahkan investor dalam pengambilan keputusan.Press release dan unaudited last quarterly result merupakan penyebab adanya perbandingan yang signifikan. Bank umum syariah di Iran dan Sudan kebanyakan tidak memiliki konsistensi dalam update beritanya, selain itu untuk laporan triwulan terbaru yang belum diaudit Bank Umum Syariah di Iran dan Sudan sama sekali tidak menampilkannya diwebsite.

\section{Kualitas User Support}

Berdasarkan uji one way anova, komponen user support IFRantara Bank Umum Syariah di Indonesia, Malaysia, Iran, Sudan terdapat perbedaan yang signifikan, dengan nilai signifikansinya $0.006<0.05$. Pada analisis deskriptif, komponen user support IFRBank Umum Syariah Indonesia lebih besar daripada komponen user supportIFRBank Umum Syariah di Malaysia, Iran, Sudan. Hal tersebut menunjukkan bahwa kualitas dari sisi user 
supportIFR Bank Umum Syariah di Indonesia lebih baik dibandingkan bank umum syariah di keempat negara tersebut.

Dari sisi user support IFR, yang menilai tentang fasilitas dan layanan yang disediakan bank syariah dalam website untuk memudahkan penggunanya, Bank Umum Syariah Indonesia memiliki kualitas lebih baik dibandingkan Bank Umum Syariah di Malaysia, Iran, dan Sudan. Ini menunjukkan bahwa Bank Umum Syariah di Indonesia memperhatikan kemudahan dan kenyamanan para penggunanya dalam mengakses websitenya.

Helpand frequently asked question (FAQ) menjadi penyebab adanya perbedaan dari sisi user support. Bank Umum Syariah di Sudan sama sekali tidak menggunakan help and FAQ pada websitenya. Padahal fasilitas dan layanan yang disediakan dalam website membuat penggunanya semakin antusias untuk mencari informasi keuangan bank umum syariah tersebut, yang tentunya akan memberi keuntungan bank syariah itu sendiri karena mampu memberikan sinyal positif kepada para pengguna informasi keuangan.

\section{Kualitas Technology}

Berdasarkan uji one way anova, komponen technologylFRantara Bank Umum Syariah di Indonesia, Malaysia, Iran, Sudan terdapat perbedaan yang tidak signifikan, dengan nilai signifikansinya $0.460>0.05$.

Berdasarkan hasil uji dapat diketahui bahwa dari sisi tehcnology IFR terdapat perbedaan yang tidak signifikan antara Bank Umum Syariah di Indonesia, Malaysia, Iran, dan Sudan.Rata-rata kualitas technology IFR dari keempat negara tersebut cenderung rendah. Hal itu disebabkan karena sebagian besar bank umum syariah di keempat negara tersebut bukan merupakan perusahaan go public. Perusahaan go public kepemilikan sahamnya memiliki potensi lebih besar untuk dimiliki oleh orang seluruh dunia, sehingga pemanfaatan pelaporan keuangan melalui website sangat dimaksimalkan apalagi dari sisi technologynya seperti, download plug in, online feedback, use presentation of slides, use multimedia technology, analysis tool, advance features. Untuk komponen teknologi advance features dan presentation slide tidak ada satupun Bank Umum Syariah di Indonesia, Malaysia, Iran, dan Sudan yang menggunakan technology tersebut dalam website mereka. Hal tersebut yang menjadi penyebab adanya perbedaan yang tidak signifikan di keempat negara tersebut.

\section{SIMPULAN}

Berdasarkan hasil uji dapat diketahui bahwa terdapat perbedaan yang signifikan pada kualitas Internet Financial Reporting, komponen isi/content, komponen timeliness/timeliness, dan komponen dukungan pengguna/user support antara Bank Umum Syariah di Indonesia, Malaysia, Iran, dan Sudan. Sementara untuk komponen technology terdapat perbedaan yang tidak signifkan antara Bank Umum Syariah di Indonesia, Malaysia, Iran, dan Sudan. 
Secara kesuluruhan kualitas pengungkapan laporan keuangan melalui webiste Bank Umum Syariah di Indonesia lebih baik dibandingkan Bank Umum Syariah di Malaysia, Iran, dan Sudan.Penyebab nilai rata-rata Internet Financial Reporting Bank Umum Syariah di Indonesia lebih tinggi adalah kurang lengkapnya informasi keuangan yang diberikan, kurang konsisten dalam update informasi keuangan, serta kurangnya fasilitas atau layanan yang terdapat pada website Bank Umum Syariah di Malaysia, Iran, dan Sudan.Selain itu, dari segi regulasinya Bank Umum Syariah di Indonesia memiliki sanksi yang tegas yang berhubungan dengan pelaporan keuangan.

Berdasarkan hasil penelitian, analisis, pembahasan, dan kesimpulan yang diambil, maka saran yang dapat diajukan yaitu Bank Umum Syariah di Indonesia, Malaysia, Iran, dan Sudan, agar melakukan pelaporan informasi keuangan melalui website secara maksimal sesuai dengan IFR yang meliputi empat komponen (content, timeliness, technology, user support). Selain itu, dari sisi technologynya agar lebih ditingkatkan lagi untuk memudahkan investor memperoleh informasi keuangan.

Untuk peneliti selanjutnya, diharapkan agar melakukan penelitian tentang faktorfaktor yang menyebabkan tingginya kualitas IFR suatu bank syariah, serta melakukan penelitian tentang hubungan kualitas IFR dengan kinerja bank umum syariah. Sementara untuk regulator di Indonesia, Malaysia, Iran, dan Sudan, agar memberikan peraturan mengenai standar pelaporan keuangan melalui website/Internet Financial Reporting denganmemperhatikanempatkomponen(content, timeliness, technology, usersupport).

Selain itu, bagi Malaysia, Iran, dan Sudan agar menambahkan peraturan mengenai sanksi apabila tidak memberikan informasi keuangan secara lengkap dan tepat waktu.

\section{DAFTAR PUSTAKA}

Agboola, A. A., \& Salawu, M. K. (2012). The determinants of internet financial reporting: Empirical evidence from Nigeria. Research Journal of Finance and Accounting, 3(11), 95-105..

Ball, R. (2006). International Financial Reporting Standards (IFRS): pros and cons for investors. Accounting and business research, 36(sup1), 5-27..

Brigham, Eugene.F \& Houston. (2001). Manajemen Keuangan. Jilid 1.Edisi 8.Terjemahan oleh Dodo Suharto, Herman Wibowo, dan Yati Sumiharti. Jakarta: Erlangga.

FASB.(2000). Business Reporting Research Project Electronic Distribution of Business Reporting Information. Steering Committe Report Series,1, (http://fasb.org/, diakses 30 April 2018).

Handayani, E., \& Spica Almilia, L. (2013). Internet Financial Reporting: Studi Komparasi Perusahaan Manufaktur yang Terdaftar di Bursa Efek Indonesia dan Bursa Efek Malaysia. Jurnal Bisnis dan Ekonomi, 20(2). 
Analisis Perbandingan Internet Financial Reporting....

IASC.(1999). Business Reporting on the Internet.International Accounting Standards Committee, 48.

Indonesia Stock Exchange.(2015). Tentang XBRL, (Online), (http://idx.co.id/, diakses 30 April 2018).

Internet World Stats. (2017). Internet Usage in Asia, (Online), (www.internetworldstats.com, diakses 10 Januari 2018).

INSANI, T. D. (2016). Analisis Perbandingan Kualitas Internet Financial Reporting Bank Umum Syariah Di Indonesia Dan Malaysia (Doctoral dissertation, UNIVERSITAS AIRLANGGA)..

Khan, M. N. A. A. (2015). Internet financial reporting in Malaysia: Preparers' and users' perceptions. Procedia-Social and Behavioral Sciences, 172, 778-785.

Munir.(2012). Multimedia Konsep dan Aplikasi dalam Pendidikan. Bandung: Alfabeta.

OJK.(2015). Peraturan Otoritas Jasa Keuangan Nomor 8/ POJK.04/2015 tentang Situs Web Emiten atau Perusahaan Publik, (Online), (www.ojk.go.id, diakses 30April 2018).

Rahmawati, Finda. (2016). Analisis Perbandingan Internet Financial Reporting (IFR) pada Sektor Perbankan yang Go Public di Indonesia, Malaysia, Singapura.(Doctoral Dissertation). Surabaya. STIE Perbanas

Rizqiyah, R. N., \& Lubis, A. T. (2017).Penerapan Internet Financial Reporting (IFR) Pada Bank Umum Syariah Di Indonesia. JURNAL AKUNTANSI DAN KEUANGAN ISLAM, 5(1), 63-81.

Shihab, M. Quraish. (2002). Tafsir Al-Misbah Pesan, Kesan dan Keserasian Al - Qur'an. Jakarta Pusat: Lentera Hati Jakarta: Raja Grafindo Persada.

Sugiyono.(2017). Metode Penelitian Pendidikan Pendekatan Kuantitatif, Kualitatif, dan $R D$. Bandung: Alfabeta.

Taswan.(2008). Akuntansi Perbankan Transaksi dalam Valuta Rupiah. Yogyakarta: UPP STIM YKPN.

Virgiawan, I. P. Y., \& Diyanty, V. (2015). Pengaruh Konsentrasi Kepemilikan Keluarga Dan Internet Financial Reporting (Ifr) Terhadap Asimetri Informasi. Jurnal Akuntansi dan Keuangan Indonesia, 12(2), 123-146.

Wiroso.(2011). Akuntansi Transaksi Syariah. Jakarta: Ikatan Akuntansi Indonesia.

Wisnumurti, A., \& YUYETTA, E. N. A. (2010).Analisis Pengaruh Corporate Governance terhadap Hubungan Asimetri Informasi dengan Praktik Manajemen Laba (Studi 
Hayati dan Suprayogi | Jurnal Ekonomi dan Bisnis Islam, Vol. 4, No. 1, Januari-Juni 2018

pada Perusahaan Perbankan yang Terdaftar di Bei) (Doctoral dissertation, UNIVERSITAS DIPONEGORO).

Yusuf, Muri. (2014). Metode Penelitian Kuantitatif, Kualitatif, dan Penelitian Gabungan. Jakarta: Prenadamedia Group. 